\title{
Lead Placement McFee-Parungao
}

National Cancer Institute

\section{Source}

National Cancer Institute. Lead Placement McFee-Parungao. NCI Thesaurus. Code C71119.

An electrocardiogram (ECG) lead placement for determining 3 orthog onal components $X$ (back to front), Y (right to left) and Z (foot to head) of the heart. This system places the electrodes closer to the heart to achieve better orthogonality and a homogeneous lead field. 